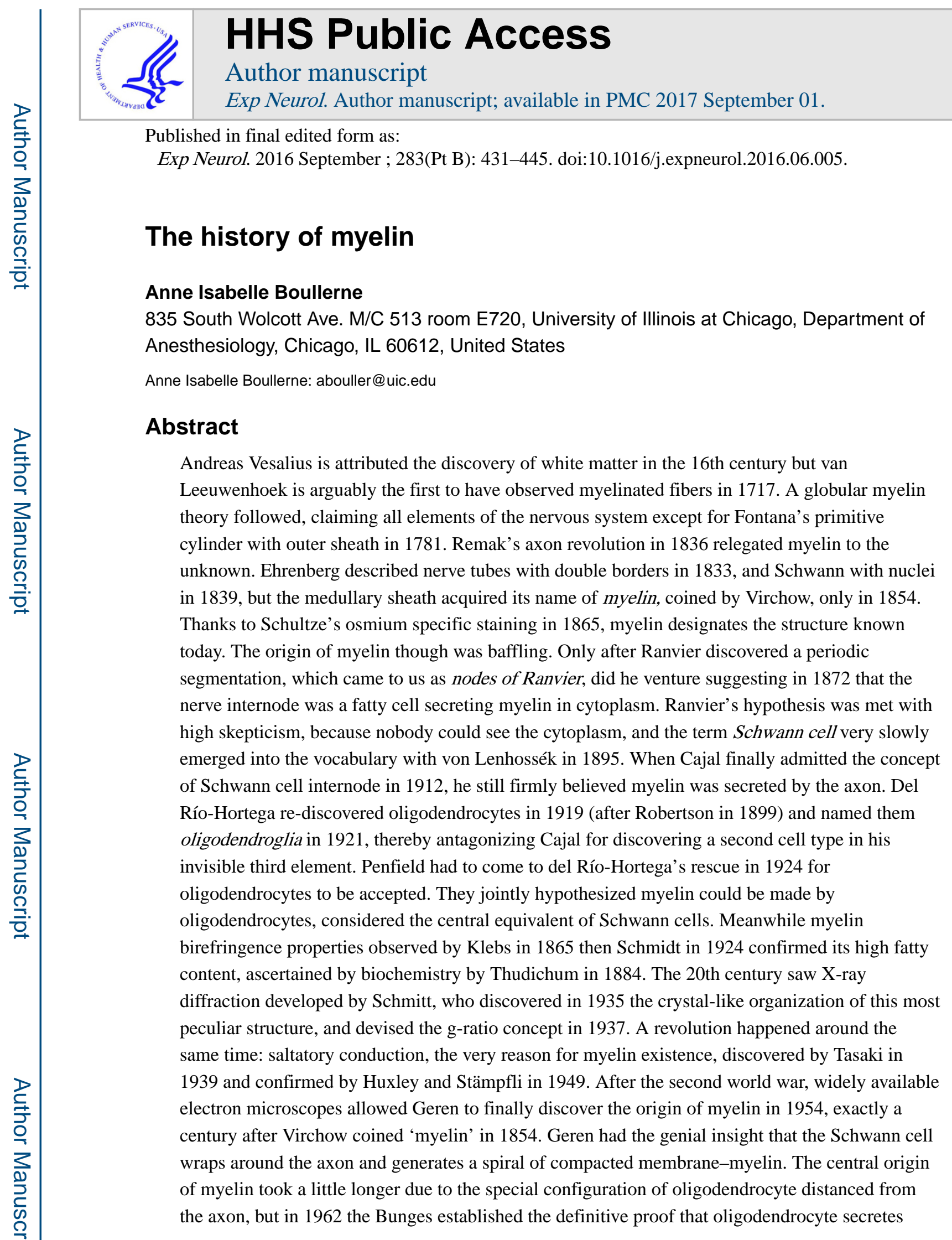

Declaration of interests

The author declares no conflict of interest and assumes all translations where not specified. Accessing original documents generated discrepancies with their formerly cited references. 
myelin. The era of myelin biology had begun. In 1973 Norton devised a method to purify myelin which launched the modern molecular era.

\section{Keywords}

Myelin; History; Invertebrates; Oligodendrocyte; Schwann cell

\section{Before myelin was myelin}

\subsection{Vesalius first mention of white matter}

The renaissance physician Andreas Vesalius (1514-1564 $\dagger$ ), considered the father of modern anatomy, was the first to describe white matter and gray matter in the human brain in a monumental treatise known as ' $\mathrm{La}$ Fabrica' illustrated with many detailed anatomical drawings (Vesalius, 1543). Vesalius, born Andries van Wesel in Brussels, was encouraged early by his family to become physician, his grandfather being the Royal Physician of Emperor Maximilian. Vesalius became Professor at the University of Padua and later himself Imperial physician at the court of Emperor Charles V. Since an early age Vesalius dissected cadavers he was stealing in cemeteries and from executed criminals. He published his tome La Fabrica at 28 year-old, thereby correcting many errors from the Greek Galen who had only access to animals, and stirred many disagreements among scholars at the time (Zalc and Rosier, 2016). Galen had described the corpus callosum in animals, but the white and gray matter were not distinguished from each other in antiquity. The renaissance also saw the emergence of cerebrum and medulla (Schmahmann and Pandya, 2007).

\subsection{7 van Leeuwenhoek first description of myelinated fibers}

The first to describe myelinated fibers is arguably Antoni van Leeuwenhoek (1632-1723 $\dagger$ ), draper from the Netherlands Delft (Fig. 1). He was extremely gifted, grinding his own lenses and endowed with avid curiosity, regularly publishing in the London Philosophical Transactions of the Royal Society. He described myelinated fibers in a letter dated 2 March 1717 (pages 310-313 in English by Clarke and O'Malley, 1968): “Often, and not without pleasure, I have observed the structure of the nerves to be composed of very slender vessels of an indescribable fineness, running lengthwise to form the nerve. The diameter of the vessels is such that if you compare it with its canal, it is a third larger than the canal." (van Leeuwenhoek, 1719). Van Leeuwenhoek lamented further that in less than a minute the central lumen of these minute tubes would collapse (Fig. 1). He used a lovely image: "Just as if we were to perforate a piece of paper in certain places with a very fine needle and look at the sun shining through those holes". Van Leeuwenhoek is credited for naming the nervous fiber a 'tube', but he took the secret of his lenses to the grave. After van Leeuwenhoek a globular theory of nerves prevailed (Ranvier, 1878, page 27): "Indeed, most anatomists of last century and the beginning of this century [19th] had quite other ideas on the constitution of nerves. Since they dissociated them in water, covered them with a thick slide and probably exerted a strong pressure, they saw under the microscope a quantity of granules or globules, which they surmised composed the medullar substance of the nerve." 
Hence 18th century investigators concluded myelin globules composed the integral part of nerves.

\subsection{Fontana primitive cylinder with outer sheath}

Determining the nerve elementary structure was a main concern for physicist and naturalist Felice Gaspar Fontana (1730-1805†), creator of the Physics and Natural Sciences Museum in Florence appointed by the Tuscany grand duke (Fontana, 1781, page 203): "whether it is composed of channels or of simple threads; whether it consists only of globules or whether it contains a non-organic, irregular, spongy substance". Teasing a nerve with extremely fine needles in a drop of water, Fontana finally obtained (page 204) "several very small, more or less transparent, cylinders ... that I shall name primitive nervous cylinders". Not yet convinced, Fontana used his most powerful lenses magnifying 800 fold that revealed the elementary cylinders had a rough less transparent outer envelope made of extremely fine threads. Surprised, Fontana noticed that, despite their extreme slenderness, the threads almost doubled the cylinder thickness through extreme accumulation of curling and coiling (Fig. 1). Fontana concluded these cylinders were the elementary structure of nerves (page 207): "The nerve is composed of a large number of transparent, homogeneous, uniform, and very simple cylinders ... Each of these cylinders is endowed by an envelope in shape of outer sheath, which is composed of an immense number of winding threads ... and are the simple and basic organic elements of nerves, because I could never succeed in dividing them further, no matter the sharpest needles." Fontana's observations were remarkable for his time, noting similarly as van Leeuwenhoek that the sheath thickness was almost half the axon diameter. Fontana's observations were corroborated a century later by Ranvier who reported that myelin in water finely disheveled in a myriad of filaments (Ranvier, 1878).

\subsection{Ehrenberg double contour tube}

The next significant contribution was made by Christian Gottfried Ehrenberg (1795-1876†), a scientific hero to the Berlin school (Schwann, Schleiden, von Kölliker, Virchow...), one of the last universal scientists who traveled to Siberia with Alexander von Humboldt (Prof. Kettenmann, Berlin Max Delbrück Center, personal communication). Ehrenberg was instrumental to the microscope revolution in Germany in the 1830s and felt compelled to mention the Berlin manufacturer: "Since the year 1834 I use a new and the strongest microscope from Pistor and Schiek and have therefore frequently confirmed and extended my observations". Ehrenberg acknowledged van Leeuwenhoek's anatomy, and (re)established the fibrillary nature of the nervous system in teased preparations (Ehrenberg, 1833). Ehrenberg had to create a new terminology besides the Latin word medulla (Medullar-Substanz) simply designating white matter since the 15th century. He differentiated varicose (structured as beads on a string) 'brain tubes' (Hirnröhren) from the cylindrical 'nerve tubes' (Nervenröhren). Varicosities are well-known in freshly dissected central nervous system (CNS) fibers by lack of endoneurial sheath (Rosenbluth, 1999). The great merit of Ehrenberg was to suggest a continuity between gray and white matter, and between spine and peripheral nerves. But he conceived the nervous tubes similarly as van Leeuwenhoek vessels (Ehrenberg, 1833, pages 452-454): "The interior of varicose brain tubes is overall quite limpid, so that they could be held for transmitting mist or water ... This milk color is absent in the cortical substance, which consists of the tips or beginnings of 
varicose brain tubes, and thus indeed possess the tube walls, but lack the voluminous contents thereof. From this it seems reasonable to conclude that the white color is inherent in particular to the content of the brain tube ... The cylindrical simple nerve tubes, however, possess an essential difference from the structured brain tubes, for they have a much larger internal cavity, and enclosed there is a very noticeable, less transparent content which has long been recognized ... By transverse section of each nerve its sinewy sheath ... is of white color. This is marrow substance." Noticeably Ehrenberg reserved the term double wall (doppelter Wandung) for peripheral fibers and his drawing clearly showed four parallel lines (Fig. 1). Ehrenberg great merit, in contrast to his predecessors, was to specify for the first time that nerve marrow meant strictly the sheath, and not the whole nerve fiber. His precise terminology for myelinated 'marrow tube' (markführende Röhre), composed of a sheath of 'nerve marrow' (Nervenmark) around a 'brain tube' (Hirnröhre) paved the way for Remak fundamental discovery of the axon.

\subsection{Remak primitive band}

Robert Remak (1815-1865†), embryologist who established the three fundamental embryonic layers, dabbed in neurology as student of Johannes Müller in Berlin University. Remak was allowed to use Müller's and Ehrenberg's excellent microscopes (Clarke and O'Malley, 1968). His first paper described that the myelin sheath was acquired by nervous fibers during development in rabbit spinal roots and he used a new terminology (Remak, 1836 first sentence): "We learned from Ehrenberg's investigations that ... the brain is composed of varicose marrow-less primitive fibers (marklosen Primitivfasern), while nerves are composed of cylindrical marrow fibers (markhaltigen Fasern)." Remak described for the first time a fiber not conceived as hollow (Primitivfasern), in contrast to Ehrenberg's tubes. Remak then coined the better term of primitive band (Primitiv Band), pointing out with candor (Remak, 1837, page 39): «it would be possible that the content of the primitive band was originally cylindrical and the flat form incurred by the pressure of the observation slide". Remak primitive band was made of a pale homogeneous substance, without double line at the edges, contained no marrow (myelin), and absolutely no wrinkle in contrast to the rough appearance of myelinated fibers. Remak concept of axon (primitive band) was breaking away profoundly with the old conception dating back from the Antiquity, viewing nerves as hollow channels transmitting animal spirits. Remak truly re-conceptualized the nervous elementary structure. His medical dissertation in Latin (Remak, 1838) further expanded on the pellucid primitive fiber denuded of sheath (Fibra primitiva pellucida vaginâ denudata) and named the sympathetic unmyelinated fibers 'organic fiber' (fibra organica) (Fig. 1). Interestingly, Remak may have borrowed his terms from Fontana's primitive nervous cylinder and basic organic element, acknowledging Fontana had seen the primitive band (Remak, 1838). It should be noted that Remak was the first to describe nuclei on unmyelinated organic fibers (Remak, 1838), but Schwann ended up credited for discovering them (Jacobson, 1993). Remak concept of axon was not immediately unanimously accepted because of the competing globular and animal spirit theories. The terms Remak's bands or fibers persist to this day designating unmyelinated pain peripheral nerve fibers. 


\subsection{Schwann sheath and nuclei}

Theodor Schwann (1810-1882†) worked with Johannes Müller then moved to Belgium in 1839 for the chairs of Anatomy at Louvain then Liège University. That same year Schwann and Schleiden published a textbook famous for enunciating the cell theory (Schwann, 1839). Regarding myelin, Schwann disliked the common term marrow and renamed it white substance. He described the nervous fibers as composed of two types: common white nervous fibers and gray so-called organic fibers, hence adopting Remak terminology. Schwann is credited for discovering two key elements: neurilemma and its nuclei (pages 146-147 in English translation, 1847): "The white substance [myelin] of each nerve is surrounded externally with a structureless and peculiar membrane, which appears to be minutely granulated. This membrane presents itself as a narrow, clear border, which is readily distinguished from the dark contours of the white substance." The sheath of Schwann should not be confused with the myelin sheath. In numerous instances, von Kölliker and Ranvier stated that central myelin lacked the sheath of Schwann. Indeed, there is no cytoplasm lining myelin in CNS since the oligodendrocyte plasmatic membrane fuses with myelin. The terms 'membrane of Schwann' and 'sheath of Schwann' were used quite interchangeably in the 19th century literature and is a source of ambiguity. Rudolf Albert von Kölliker (1817-1905†), Swiss histologist in Würzburg University, very influential in 19th century across Europe for demonstrating with brilliant clarity that axons arose from nerve cells, credited Schwann for naming myelin white substance and separately discovering a thin sheath, which was actually much more difficult to observe than myelin (von Kölliker, 1855). In a subsequent edition of his manual for medical students he used the term "Schwann'sche Scheide" (Schwann's sheath), sealing the association of Schwann with the neurilemma (von Kölliker, 1863). Schwann noticed nuclei on nerve fibers particularly during development before myelination, and was quite surprised to still see nuclei once the fibers were myelinated (Fig. 1). Schwann proposed these nuclei were a remnant of an earlier stage when they formed a continuous chain of cells that coalesced to form the nerve fibers, formulating the enduring cell-chain or catenary theory (Kettenmann and Ransom, 2005).

\section{Myelin acquires a name}

\subsection{Virchow coins myelin}

The word Myelin was coined by German pathologist Rudolf Ludwig Virchow (1821$1902 \dagger$ ), author of the fame Neuroglia term (Kettenmann and Ransom, 2005). There was much confusion mid-19th century regarding the medullary substance, and Virchow expressed the need for a better terminology in Virchow's Archiv, the journal he founded (Virchow, 1854, page 571): "das Bedürfniss, sie mit einem Worte bezeichnen zu können, vorliegt, so schlage ich vor, um jede Verwechselung mit anderen schon bezeichneten, aber noch problematischen Substanzen zu vermeiden, sie Markstoff, Myelin zu benennen. The necessity exists of being able to identify a word, so I suggest, to prevent any confusion already created by others and avoid more problematic substances, to name the marrow material myelin." Myelin derives from the Greek myelos after bone marrow color and texture (medulla in Latin). Nevertheless, Virchow article entitled "On the disseminated occurrence of a substance analogue to nerve marrow in animal tissues" suggested myelin was quite a floating term, and discussed a substance found in sicken lung and other tissues.

Exp Neurol. Author manuscript; available in PMC 2017 September 01. 
In his landmark textbook on cellular pathology Virchow (1858) gave myelin wide exposure, but did not strictly anchor it to the nervous system (pages 234-235 in English translation, 1860):" From blood-cells, from pus-corpuscles, from the epithelial cells of the most various glandular parts, from the interior of the spleen and similar glands unprovided with excretory ducts, this substance can in every case be obtained by extraction. It is the same substance which forms the principal constituent of the yellow mass of yolk in the hen's egg, whence its taste and peculiarities, especially its peculiar tenacity and viscidity which are employed for the higher technical purposes of the kitchen, are familiar to every one. It is this substance, for which I have proposed the name of medullary matter (Markstoff), or myeline, that in extremely large quantity fills up the interval between the axis-cylinder and the sheath in primitive nerve-fibres." The following decade showed occasional use of myelin for equally various attributions.

\subsection{Schultze magic osmium stain}

The discovery a decade later of osmium stain changed everything. Max Schultze (1825$1874 \uparrow$ ), Professor in Bonn and friend of Otto Deiters (Kettenmann and Ransom, 2005), published in the first issue of his journal that a weak solution of perosmic acid was excellent to contrast and harden tissues (Schultze and Rudneff, 1865, pages 301-303): "Next after the fats is the nerve marrow, which takes exceptionally quickly osmium staining ... A nerve cord freshly taken from the animal turns deep blue black ... Bundles of medullated fibers, which are embedded in gray matter, or individual fibers that were previously hard to see, come forth now with great sharpness ... It is obvious that with the help of this staining method a number of important questions will be solved, and that a great future lies ahead for the osmium staining in the anatomy of the brain and spinal cord". Osmium staining was disseminated further through a chapter in the wildly popular Stricker Handbuch (Schultze, 1871). A decade later, Ranvier in his seminal $1875-1885$ and 1878 books published crisp illustrations of osmium-stained myelinated axons (Fig. 2). Ranvier, technological wizard who devoted several chapters to the study of osmic acid, "a reagent of paramount importance for the study of the nervous system" (1878), gave the key why myelin thereafter was not confused with other tissues (1875-1885, page 108): "Osmic acid is not only used to harden tissues, but moreover to color certain elements in more or less intense black, with brown or blue hues. Hence myelin is colored in blueish black and the fat in brownish black." Ranvier mentioned that despite osmic acid fumes were toxic and dissections carried behind a glass wall to avoid conjunctivitis, all histologists used it. Giving beautiful black and white renditions, osmium was far superior to carmine, and had another welcome property to retain the natural anatomy, preventing myelin 'coagulation' in globules. Obviously with a great future, osmium is used to this day in electron microscopy.

\section{From chaos to organization}

\subsection{Charcot myelin droplets in multiple sclerosis}

In 1868, the neurologist Jean-Martin Charcot (1825-1893†) used myelin (myéline) in what can be considered its first correct attribution. Charcot was an avid and respectful reader of German literature, until the 1870 French-German war dampened his enthusiasm (Guillain, 1955). Charcot established at the Parisian hospital Salpêtrière the clinical and histological 
criteria to diagnose multiple sclerosis in two articles. The histology article described demyelination in lesions (Charcot, 1868, Fig. 2) expanded the following year by two Charcot residents (Bourneville and Guérard, 1869, pages 46-48): "At the heart of the sclerotic lesion, we find almost constantly globules or granules with fatty element appearance ... These myelin drops and fatty granules can infiltrate the mesh of the reticulum and spread wide; they never occupy the center of the sclerotic plaque, since there, the fibrillary metamorphosis and the destruction of the nervous tubes are completed; but, on the contrary, one finds them at the plaque edges, where the medullated cylinder disappears progressively ... The nervous tube is thus finally reduced to the axis-cylinder. Accumulation of the medullary or fatty droplets coincides with the destruction of the myelin sheath, and ceases to happen when completed. We can hence conclude that the medullary and fatty corpuscles are only the rubbish from the disintegration of the nervous tubes. "This surprisingly accurate description matches the multiple sclerosis lesion stages known today.

\subsection{Ranvier discovers the nodes}

Louis-Antoine Ranvier (1835-1922†), chair of Anatomy at Paris Collège de France, was interested as much in structure as in function, having trained with homeostasis physiologist Claude Bernard (Boullerne, 2011). He loved experimenting on myelin, studying its swelling and disheveling in water, and observed that water stopped nerve conduction. Ranvier (Fig. 2) was struck by the beauty of fresh myelinated nerves he compared to silk having a wavy lustrous finish (1878 page 24): "white, more or less opaque, shimmering and sparkling as moire”. Ranvier mastered many staining techniques, including classic carmine used by Austrian ophtalmologist Ludwig Mauthner (1840-1894 $\dagger$ ), who first reported the concentric organization of myelin (Fig. 1) and his eponymous periaxonal sheath underneath myelin (Mauthner, 1860). Using carmine and silver nitrate in mouse thoracic and rabbit sciatic nerves, Ranvier noticed myelinated axons were stained only at regular intervals. He realized myelin had periodic gaps allowing stains to access the axon. Intrigued, Ranvier used a powerful lens to dismiss a possible artifact:" Indeed, under 800 diameter magnification, the nerve tube constriction seems formed by a narrow convex ring confounding itself with the Schwann membrane ... that I shall designate by the name of constricting ring (anneau constricteur)" (Ranvier, 1871). Ranvier soon provided a much needed drawing (Fig. 2), and especially used osmic acid to confirm that myelin was absent at the level of the node (Ranvier, 1872). Osmium-blackened myelin glaringly revealed Schwann nuclei nested in the sheath. Surprised, Ranvier determined two important facts: 1) there is only one nucleus per internode, and 2) located at equal distance from each node. Several additional rules were internode is proportional to the fiber diameter (the larger the axon, the longer the internode); protoplasm surrounding nucleus extends from node to node; internode elongates during development (Ranvier, 1872). He wondered why, considering the power of osmium, prominent histologists had not formerly observed the nodes (1878, page 52): "we only see easily the facts on which one's attention is already attracted. "Ranvier mentioned that only a certain Johann Czermak (1849) from Breslau drew nodes with remarkable acuity as constriction (Einschnürung). At any rate nodes were vaguely represented sporadically but dismissed as artifacts. Remak actually provided the earliest node outline with the legend: "constriction, as seen very frequently on all fibers" (1836). It seems Ranvier's nodes (Ranvier'schen Schnürringe) was universally accepted rapidly. Unfortunately Ranvier 
forcefully claimed the nodes did not exist in CNS, and easily dismissed contemporaries who reported them (Tourneux and Le Goff, 1875). Aggravating this fact, the other towering figure von Kölliker also did not believe in CNS nodes. They both had such an enormous influence that doubt persisted well until Santiago Ramón y Cajal (1852-1934†), Nobel Prize winner with Camillo Golgi in 1906 for the neuronal theory and founder of the Spanish school of neuroscience, imposed nodes centrally (pages 269-270 in Cajal monumental tome of 1909-1911 vol1). The topic was not contentious anymore with von Kölliker passed away and Ranvier retired living in seclusion.

\subsection{Incisures of Schmidt and Lanterman}

The sideways incisures present in thick myelin were discovered by two Americans since fallen back into obscurity. H. D. Schmidt from New Orleans reported incisures in fresh nerves after four years of observation, well aware of the skepticism he would meet (Schmidt, 1874). His drawing of incisures in fresh nerves were not forceful tough, and his discovery was rescued by A.J. Lanterman from Cleveland working in Strasbourg (Lanterman, 1877). Lanterman was intrigued by the "hitherto hardly noticed structure in myelinated nerve fibers" and used osmium, thereby producing striking rendition of the incisures. This immediately convinced the scientific community as 'Schmidt and/or Lanterman incisures'. Cajal described their complex shape (1909-1911, page 258 vol1):" These incisures partition the myelin of the internode in a number of rings or cylindrical portions of highly variable volume, interleaved or standing against their basis ... These incisures are veritable complete infundibuliform partitions, located all around the axon." The role of these incisures was baffling everybody, and were simply attributed a myelin partitioning, despite stain differences from the nodal true 'cellular cement'. By the turn of the 20th century, the complete peripheral internode structure was explained by Cajal in his nervous system histology encyclopedia (1909-1911, page 254 vol1) spelling $a$, Schwann sheath; $b$, transversal disc and Ranvier constriction; $c$, bands of Frommann; $d$, Mauthner sheath; $e$, cylindrical cones of myelin; $f$, Lanterman incisures; $g$, perinuclear protoplasm; $h$, nucleus; and $i$, axis-cylinder (Fig. 2).

\section{Guessing myelin origin}

\subsection{Ranvier myelin is made by internode adipocyte}

Ranvier, a sagacious observer particularly tracking staining artifacts, realized both sheaths of Schwann (1839) and Mauthner (1860) were not simple envelopes but contained a sheet of cytoplasm running from node to node. The question of whether there was cytoplasm in these sheaths was not trivial, because there was no specific stain for cytoplasm at the time. Ranvier hence boldly envisioned the axon enveloped by a muff of cytoplasm with finite boundary at the nodes. All cellular elements being present: plasmatic membrane, single nucleus and cytoplasm containing myelin, allowed Ranvier to formulate the hypothesis that an internode equated to a sort of elongated adipocyte secreting myelin inside its cytoplasm (Ranvier, 1872). In subsequent textbooks he greatly expanded the analogy with a fat cell pierced by the axon (Ranvier, 1875-1885; Ranvier, 1878). He speculated further, to the disbelief of his peers, that Schmidt-Lanterman incisures were remnant cytoplasmic bridges between the Schwann and the Mauthner sheaths, after myelin secretion had completed and filled most the 
cytoplasm. Ranvier revolutionary hypothesis of a fat cell rolled around the axon paved the way toward the Schwann cell concept. Ranvier himself never wrote 'Schwann cell' because his hypothesis was highly speculative. The term slowly emerged in the following decades. One of the first instances of Schwann cell (Schwann'schen Zellen) is by Michael von Lenhossék in the same textbook he coined astrocyte (von Lenhossék, 1895). Jean Nageotte (1866-1948†), successor of Ranvier at the Collège de France, adhered early to the prevailing concept that the 'cell of Schwann' was restricted to the nucleus surrounded by a heap of cytoplasm (Nageotte, 1910). Schwann cell at the beginning was viewed as a tiny flat sheath cell apposed to myelin with various opinions on its cytoplasmic boundaries.

\subsection{Cajal and Nageotte axon makes myelin}

Cajal enunciated in 1909-1911 the prevailing opinion (page 264 vol1): "Regarding myelin, far from being the content of a corpuscle the axon would cross, it would be a simple secretion product from the axon itself." He did not see any cell in the peripheral internode, simply assuming the nucleus was an integral part of the Schwann membrane, because it easily detached from myelin like an orange peel. Cajal however shifted his view after investigating cytoplasm, thereby sealing his acceptation of the 'cell of Schwann' (Cajal, 1912, page 223): "Ranvier had a brilliant intuition when he considered the interannular segment of the nerve tube as a vast cellular unit, within which was the axis-cylinder [axon] and the inclusions of cylindrical cones of myelin." Cajal was seduced by the beautiful rendition of cytoplasm using a new methylene blue method (Nemiloff, 1910). Methylene blue stains the nucleic acids of cytoplasm synthesis organelles, which allowed Cajal to visualize the entire layer of cytoplasm from node to node. Cajal dutifully listed all Schwann cell structural elements with the glaring omission of myelin. Cajal still believed axon secreted myelin, and that myelin 'possesses' Schwann corpuscles (mielina posee corpúsculos de Schwann) presumably for support (Cajal, 1912). A year later, after his ultimate gold sublimate impregnation stained virtually all astrocytes, Cajal grew frustrated by the adendritic and apolar cells he still could not see, and dubbed them 'third element' (Cajal, 1913). He ventured to compare the white matter apolars to Schwann cells, based on their mutual exclusion from peripheral nervous system (PNS) and CNS. He surmised their presence filled a physiological role, but not based on any capacity to make myelin. Cajal, like Nageotte and his contemporaries, could not see any physical link between the axon and white matter apolar cells so how could they make myelin? Cajal speculated apolar cells in satellite perineuronal location around the soma had a perfect physiological symbiosis with neurons (Cajal, 1913). The Schwann cell in Cajal model was doing the same: support the axon make myelin.

It is quite difficult to pinpoint when and who first formulated the false theory of myelin axonal origin, but it certainly got broadcasted in a few high profile books. Nageotte wrote a chapter in one of them (Nageotte, 1932), in which he clearly explained why axon made myelin in absence of physical link between myelin and glial cells (pages 200-201): "I shall say simply that the fibers of the central system possess a sheath of myelin constructed exactly like that of the peripheral nerve fibers, with easily demonstrable nodes and incisures. Now, whatever relations may exist between the central fibers and the oligodendritic cells of the neuroglia, it is impossible to see in the myelin a territory belonging to these cells, which 
amounts to saying that it forms a part of the neurite itself. The topographic relations, then, between the segments of myelin and those of the Schwann sheath are purely physiological and everything indicates that in this association of heterogeneous segments, it is the myelin that takes the initiative." The theory of an axonal origin was deeply engrained and endured well until the 1970s.

Of note another Ranvier fellow, William Vignal (1852-1893†), the first to represent individual Schwann cells against the erroneous syncytium theory (Jacobson, 1993), was particularly interested by nerve development (Vignal, 1889). He used osmium to track myelin formation and elegantly showed that the first thin layer of myelin hugging the axon underneath the 'connective' or 'sheath' cell (Schwann cell) was weakly stained by osmium. He interpreted that myelin was still mingled with albumin material inside the protoplasm, from which it was not yet completely separated. As myelination progressed, myelin was stained darker by osmium in a more 'perfect' manner. Unfortunately, Vignal attributed the cytoplasmic muff to the axon, thus also believing myelin was secreted by the axon.

\subsection{Del Río-Hortega oligodendroglia could make myelin}

The question of who first suggested myelin is made by oligodendrocyte is not easy to answer. We should perhaps start by the context surrounding the discovery of oligodendrocytes. Oligodendrocyte were first stumbled upon by the Scottish William Ford Robertson (1867-1923†) in 1899 using a lengthy platinum impregnation over several months which revealed small branched cells (Robertson, 1899). Because these new cells had a strikingly different morphology than neurons or classic neuroglia (astrocytes) and uniquely took platinum, Robertson referred to them as 'mesoglia' basing his belief on their mesodermal origin (Robertson, 1900). It was the first time ever cytoplasmic expansions of oligodendrocytes were visible, but Robertson never made any connection between mesoglia cells and myelin that he considered a separate entity. A controversy exists as to which exact cells Robertson stained, whether oligodendrocyte, microglia, or both. However, as pointed by Wilder Penfield: "the method was so unreliable that it never found its way into laboratories outside of Edinburgh" (Penfield, 1928). Nevertheless, to honor the memory of Robertson pioneering work, del Río-Hortega, concurring with Penfield, named a subpopulation of oligodendrocytes the "Robertson cells" (del Río-Hortega, 1928).

The rightful discoverer of oligodendrocyte is Pío del Río-Hortega (1882-1945†) who in 1912 moved to Madrid to join Cajal's disciple Nicholás Achúcarro and study neuroglia, learning precious metal impregnation techniques. The following years del Río-Hortega perfected histology during stints abroad in Paris, Berlin and London that led him to develop the famous silver carbonate method, which eventually succeeded to capture Cajal's third element. He revealed not one, but two new cell types he named microglia and interfascicular glia (del Río-Hortega, 1919). This publication triggered the ire of Cajal and, joined to the premature death of his protector Achúcarro, forced del Río-Hortega to leave Cajal laboratory and establish another laboratory in the Residencia de Estudiantes some $2 \mathrm{~km}$ away (del RíoHortega, 2013). The same year he formally introduced interfascicular glia as oligodendroglia (del Río-Hortega, 1921). Silver carbonate revealed oligodendroglia cytoplasmic processes spiraling around unstained myelin (Fig. 2) in a manner reminiscent of Schwann sheath. A 
year later he cautiously ventured comparing oligodendroglia to Schwann cells, while reverentially substantiating Cajal hypothesis (del Río-Hortega, 1922) and soon published in French for international outreach (del Río-Hortega, 1924). Axon wrapping by oligodendroglia and Schwann cell pointed to similar physiological functions, as stated in the last sentence (del Río-Hortega, 1922, English translation 2012): "We are inclined to believe, however, that both kinds of cells carry out identical functions of support, isolation, and nutrition connected with nerve conduction”. Del Río-Hortega was conflicted on the origin of myelin and presented pro and con arguments (del Río-Hortega, 1922). His main argument against the prevailing Cajal and Nageotte belief of axonal origin was discovering centrally an ensheathing cell. However the evidence was only circumstantial since he could not establish a physical link between myelin and oligodendroglia.

\subsection{Penfield support for oligodendroglia}

The situation was frozen with Cajal, who refused to use del Río-Hortega exact procedure out of pride (Cajal created excellent methods used to this day), and could never stain oligodendrocytes. Del Río-Hortega was embattled when in 1924 he welcomed American neurosurgeon Wilder Graves Penfield (1891-1976 $†$ ), who later founded the renowned Montreal Neurological Institute at McGill University. Penfield was fresh blood and del RíoHortega purposely wanted "a serious neurologist, hardly suggestible and a good technician to check our findings and give his valuable opinion on obscure points" (del Río-Hortega, 1928). Penfield sojourn in Madrid lasted only 6 months but was extremely productive. He published a landmark article in Brain that put oligodendroglia on the map and helped overcome Cajal skepticism (Penfield, 1924). Although the silver carbonate method was temperamental, sometimes revealing also microglia and/or astrocytes, a selective stain had oligodendroglia 'prolongations' beautifully clear-cut and much ramified (Penfield, 1924). Penfield was more explicit regarding oligodendrocytes could make myelin (Penfield, 1924, page 450): "The function of oligodendroglia cells is not settled, but their relation to nerve cells and medullary sheaths corresponds strikingly with the relation of the sheath of Schwann cells to peripheral nerves. Moreover, oligodendroglia cells appear in the CNS at the time of maximum myelinization, and contain unusually large cytoplasmic granules which suggest a secretory function. These facts, as well as the arrangement of the cells along the medullary tubes, make it probable that they have to do with the elaboration and maintenance of myelin."

Four years later del Río-Hortega published a long memoir on oligodendroglia in which he classified 4 types according to phenotype: type I included "Robertson cell" (polydendrocyte) and cells wrapping multiple small axons; type II contacted parallel axons; type III dealt with few larger axons; and type IV had a one to one relationship with the largest axons similarly as Schwann cells (del Río-Hortega, 1928). He noted the term oligodendroglia was immediately accepted by the scientific community, replacing their dozen former names. Five years later Penfield edited the first book in English on neuroglia, in which del Río-Hortega presented microglia (finally accepted by Cajal), while Penfield introduced oligodendrocytes (never accepted by Cajal). Penfield's genius was to compare oligodendrocytes alongside classical neuroglia, back then restricted to astrocytes, which facilitated their acceptance as a new cell type (Penfield, 1932). Del Río-Hortega had already appropriated for himself the 
hypothesis that oligodendrocytes generate myelin (1928, page 11 in English translation 2013): "The American neurologist agreed with our hypothesis of possible involvement of the oligodendroglia in the formation and support of the myelin sheath." We will never know who, del Río-Hortega or Penfield, first floated the idea, but we can be certain they discussed it.

\section{Myelin functions: myths and reality}

By mid-19th century, the concept of axon had replaced myelin as the essential and active component of the nervous fiber. Myelin origin and function puzzled early investigators by appearing relatively late during development and not investing all fibers in adult. The following section, by no means exhaustive or comprehensive, presents the most remarkable theories.

\subsection{Virchow insulation of medullary sheath}

Nerves were known to transmit electricity, which prompted Virchow to audaciously formulate the first insulation theory (Virchow, 1858, pages 235-236 English translation, 1860): "The axis-cylinder [axon] would therefore seem to be the real electrical substance of natural philosophers, and we may certainly admit the hypothesis which has been advanced, that the medullary sheath rather serves as an isolating mass, which confines the electricity within the nerve itself, and allows its discharge to take place only at the non-medullated extremities of the fibres."

\subsection{Ranvier theories}

Ranvier proposed several theories from his significant work on myelin (Ranvier, 1878). His elegant comparison with the transatlantic telegraph cables, operational in 1866, drew from Virchow hypothesis (page 131): «Myelin has perhaps another role; it is probably an insulating envelope. We know that electrical connections which are immersed in a conductive medium must be isolated by a non-conductive sleeve; construction of submarine cables rests on this principle. It is conceivable that transmission of the sensitive or motor impulses may have some analogy with the transmission of electricity, so perhaps each nervous tube must be isolated for this transmission to be more efficient. "Ranvier also correctly suggested myelin confers an evolutionary advantage (page 133): "Nerve tubes with myelin do not exist in invertebrates. Therefore, they are not essential to the nervous system manifestations, since many animals possess all the nervous functions: sensitivity, motility, nutrition without having myelin tubes ... The nervous tubes with myelin seem therefore constitute an improved transmission apparatus particular to the vertebrate nervous system." By far his most entertaining theory is about the nodes (page 34-35): "If liquid myelin was uninterrupted in the entire length of the nervous tube, in example in man sciatic nerve which stands vertical in our usual posture, it would glide to the lowest part by its own weight; there would not remain anymore myelin in the superior part of the nerve. But this is not the case; the myelin sheath is interrupted from distance to distance by transversal partitions which retains it." Ranvier more sensibly attributed nodes a nutritive role since myelin insulated the axon so well from dyes (page 132): "These observations allow us to conclude that the penetration of crystalloid materials or, if you prefer, the diffusible elements necessary for the 
axis-cylinder nutrition, which, as we know and as I will demonstrate, is the most important part of the nervous tube, would not easily happen if it was surrounded by myelin in its entire length ... At any rate the penetration is much faster and much easier at the level of the nodes, and we can surmise, without over speculating, that it is through them that nutrition of the axis-cylinder occurs."

\subsection{Myelin as energetic fuel}

Well before saltatory conduction was conceived, joined to a vastly unknown chemistry, the function of myelin unbridled imagination. The sixth edition of an American textbook for medical students is a telling example (Sajous, 1914, page 532): "May this supposed coating and insulating material, myelin, not be to the nerve what myosinogen is to muscle? The functioning nerve is the seat of increased combustion ... This suggests that the nodes themselves... may allow the blood-plasma to filter through them, thus bringing the oxidizing substance in immediate contact with the axis-cylinder ... Indeed, if the various features enumerated are collectively considered, it will become apparent that the myelin, or white substance of Schwann, when in contact with the oxidizing substance of the blood-plasma undergoes a reaction in which chemical energy is liberated." Recent developments have provided an interesting twist to this theory of myelin as energetic fuel. Two independent investigators, Klaus-Armin Nave based in Germany (Fünfschilling et al., 2012) and Jeffrey Rothstein in the USA (Lee et al., 2012), have shown that myelin indeed is providing energetic support to the axon, which might explain why the axon eventually degenerates upon being stripped of myelin. The fuel currency has been found to be lactate, shuttled by the oligodendrocyte to the axon, in contrast to a self-combustion of the fatty sheath itself as enunciated a century earlier.

\section{Biochemistry of myelin}

\subsection{Thudichum biochemistry of myelin}

It is beyond the scope of the present review to provide a detailed account of myelin chemical composition discovery. It was known by mid-19th century that in white matter the axons "consist of protein components very similar to muscular fibrin, the marrow sheath especially of fats from various kinds" (von Kölliker, 1863, page 105). Toward the end of the 19th century, Johann Ludwig Thudichum (1829-1901†), the founder of neurochemistry, partially characterized many lipids of myelin, including its most characteristic named galactocerebroside (Thudichum, 1884). Thudichum was much in advance for his time and his 1884 book got widely criticized and rejected (Breathnach, 2001). A sample of galactolipid purified by Thudichum was discovered by chance in London and HPLC analysis determined a purity around $85 \%$, not a minor feat for 19th century methods. At the turn of the 20th century, myelin was viewed as a semiliquid albumin-fatty substance, which chemical composition appeared one of the most complex and included "cholesterin, protagon, lecithin, cerebrin and neurokeratin" (Cajal, 1909-1911). Speculation on the actual components began in the period 1914-1920 with the pioneering studies of Koch and Koch, MacArthur and Doisy, but more accurate inputs on the chemical nature of myelin came after World War I (reviewed in Norton and Cammer, 1984). 


\subsection{Norton myelin purification method}

A recurrent problem impairing the determination of myelin composition was the lack of a purification method until the 1970s. The earliest procedures were published in 1962 by Victor Whitaker in England and Eduardo de Robertis in Argentina, who isolated multiple brain membrane fractions including nerve endings and myelin with differential and density gradient centrifugation. William Norton (1929- $\dagger$ ) at Albert Einstein College of Medicine in New York, one of the most prominent myelin biochemists of the 20th century, improved these procedures by devising a sucrose gradient to specifically purify CNS myelin, which culminated in a landmark paper (Norton and Poduslo, 1973) effectively unlocking access to studying myelin chemistry. Norton went on to a seminal work that revealed myelin contains 70-85\% lipid and 15-30\% protein depending on the source; no lipid is exclusively found in myelin but enriched; large differences in lipid composition exist between CNS and PNS; and myelin is remarkably conserved for both proteins and lipids across vertebrates (review in Norton and Cammer, 1984). Considering we are still mapping the proteins of myelin, the ultimate frontier may be differences by localization -spine versus brain areas- and by oligodendrocyte subtype. Occasional investigations on myelin proteins (lipids are virtually ignored) have uncovered differences between small and large axon myelin, but the majority of studies focus on del Río-Hortega type II oligodendrocyte myelinating small and medium axons (Butt, 2013).

\section{Saltatory conduction}

\subsection{Tasaki shows saltatory conduction}

The real function of myelin of course is saltatory transmission of nerve impulse, leaping from one node of Ranvier to the next. It was first suggested in 1925 by Canadian born Ralph Stayner Lillie (1875-1952†), Professor of General Physiology at the University of Chicago (Lillie, 1925). Lillie experimented on an iron wire, considered a valid 'passive' nerve model. In a stroke of genius, he modeled the nodes by enclosing the iron wire in a glass insulant tube with periodic breaks, and noted that electric conduction occurred surprisingly faster in a saltatory fashion. Pointedly noting the analogy with myelinated nerves transmitting impulse tenfold faster (now known up to 100-fold) than when unmyelinated, he formulated the hypothesis that ions enter the axon at the nodes and generate saltatory conduction. This was not trivial to prove, tough. Another fundamental question was to understand how the impulse is propagated through long distance without fading. A theory had proposed local circuits propagated the nerve impulse (Hermann, 1879). Sir Alan Lloyd Hodgkin (1914-1998†), biophysicist in England Cambridge University, was primarily concerned with how an impulse in frog sciatic nerves blocked by cold or pressure summed with a subthreshold electric shock (Hodgkin, 1937). Hodgkin assumed that several internodes contributed to the potential recorded at any point in the axon, and furthermore that nerve transmission incurred a significant delay at the node. Hodgkin study did prove however the existence of local circuits producing the 'electrotonic' potential, developing an impressive array of mathematical formulae in a major step toward action potential mechanism.

Concurrently Ichiji Tasaki (1910-2009†), biophysicist at Tokyo Keio University, was pursuing the study of anesthetics on isolated nerve fibers (Fig. 3). At that time, there was 
ample evidence for an outward flow of current at the nodes propagating the impulse. Tasaki observed that conduction was blocked when three or more nodes were anesthetized (Fig. 3). He concluded that the flow of outward current directed at the neighboring nodes was so strong that, even after undergoing progressive attenuation in the anesthetized region over one or two nodes, it was still capable of exciting the first normal non-anesthetized node. In other words, the action potential jumps over the anesthetized region providing it does not exceed one or two nodes, and conduction block occurs because the current becomes subthreshold (too weak). Tasaki published these findings in the American Journal of Physiology just before World War II (Tasaki, 1939). During the following years, Tasaki extended his observations that the node was the only place where an inward current can be observed, but he could not publish anymore in the USA. He had to send his manuscripts to Germany via the Siberian railroad, rerouted after 1941 by submarine via South America, and learned of their publication well after the war (Tasaki and Takeuchi, 1941, 1942). Tasaki eventually had a long career at the U.S. National Institutes of Health.

\subsection{Huxley and Stämpffi confirm saltatory conduction}

Sir Andrew Fielding Huxley (1917-2012†) shared the Nobel Prize with Hodgkin in 1963 for their discovery of the basis for action potential in the squid giant axon. The two brilliant British scientists carried out research at Cambridge University in the 1950s that laid down the foundation for modern electrophysiology. After World War II, Huxley collaborated with Robert Stämpfli (1914-2002†) in Switzerland Bern University, who was elected in 1963 at the prestigious German Academy of Sciences Leopoldina. Huxley and Stämpfli experimental studies brought measurements of the resistance and capacitance of myelin, formerly assumed to be entirely insulant, and the development of complex mathematical equations evaluating conduction velocity. Their work confirmed Tasaki's findings, and culminated in a landmark publication strongly supporting the saltatory conduction of action potential from node to node in isolated frog nerves (Huxley and Stämpfli, 1949). Saltatory conduction was soon validated in the undissected (intact) myelinated frog fiber which sealed its acceptation (Frankenhaeuser, 1952). In summary, myelinated fibers act as receiving and transmitting stations at the nodes of Ranvier, receiving the passive currents coming from the preceding node and generating a new action potential reaching the next node (Hodgkin's cycle). The conclusion of experimental research started in 1780 with Galvani and concluded in 1952 with Frankenhaeuser is that nerve conduction is electric but basically different from the current flowing in a conductive cable.

\section{Crystalline molecular organization}

\subsection{Schmidt birefringence}

Myelin optic property of birefringence was discovered only in the second part of the 19th century because of the technical aspect of microscopes. Polarized light is generated by a pair of perpendicular filters, generating positive and negative birefringence. Gabriel Gustav Valentin (1810-1883†), German physiologist in Bern University, published the first study with polarized light (Valentin, 1861). When myelinated fibers were analyzed by Theodor Albrecht Klebs (1834-1913 ), assistant of Virchow in Berlin, a positive birefringence radiating from a neutral center (axon), and a negative birefringence when viewed laterally, 
suggested a high degree of molecular organization (Klebs, 1865). Much later, Gustaf Fredrik Göthlin (1874-1949†) in Sweden Uppsala University reported two birefringence patterns in nerve fibers: a protein-dependent, and a lipid-dependent that predominated only when myelin was present (Göthlin, 1913), thereby confirming chemistry that myelin is mainly composed of fatty material. Fascinated by the deep aesthetic of polarized exquisite colors, Wilhelm Joseph Schmidt (1884-1974†) in Germany Jena University made fundamental discoveries with polarizing microscope, later confirmed by electron microscope, and laid the foundation for myelin ultrastructure. Schmidt established that the myelin sheath is composed of fluid lipoid crystals perpendicular to the axon direction and radially oriented (Schmidt, 1924). He then directed his attention to the protein elements of myelin by comparing fresh and alcohol-treated frog sciatic nerves. Alcohol extracted the lipids from myelin and replaced the positive uniaxial birefringence of lipoids by a weak negative uniaxial birefringence, also with radial optical axis, that signaled a protein fraction in myelin, not to be confused with axonal proteins orientated differently (Schmidt, 1936).

\subsection{Schmitt X-ray diffraction}

Further elucidation of myelin molecular architecture awaited more powerful techniques. This was achieved by Francis Otto Schmitt (1903-1995†) at the Massachusetts Institute of Technology (MIT), 20th century brain pioneer who mastered polarized light, spectroscopy, electron microscope, and especially developed X-ray diffraction (Fig. 3). X-ray diffraction revealed a concentric pattern in myelin (Fig. 3), and confirmed both CNS and PNS myelin across vertebrates is made of oriented fluid crystals, whose lipid long chains were "astonishingly well oriented radially" and perpendicular to the axon (Schmitt et al., 1935). A repetitive period was identified in fresh nerve myelin as a long fundamental spacing of 171 $\AA$, which Schmitt accurately translated into eight lipid molecules for two fused membranes (1935, page 145): "If the myelin sheath is made up of concentric layers of these leaflet fluid crystals, each having a thickness of eight molecules, or $171 \AA$, there would be something less than two hundred such layers even in the thickest myelin sheath and perhaps only of the order of several dozen in thin sheaths." In a major step forward, Schmitt modelized the myelin fundamental unit (Fig. 3), in which doublet of lipid bilayers were intercalated with protein sheets, the lipid polar groups facing aqueous interfaces and loosely bonding with proteins (Schmitt et al., 1941). Of note, the lipid bilayer membrane concept was established in 1925 and generalized by Schmitt through polarized light. Interestingly, polarized light also showed the presence in myelin of protein oriented both tangentially and concentrically (Schmidt, 1936; Chinn and Schmitt, 1937), which was impossible to detect by X-ray diffraction with accuracy. Schmitt determined the fundamental myelin period varied from $170 \AA$ in amphibian to $186 \AA$ in mammalian PNS (Schmitt et al., 1941). Later studies in CNS showed the myelin period is slightly shorter at $160 \AA$. In summary, mammalian nerve myelin in fresh state consists of two lipid bilayers, each about $5.5 \mathrm{~nm}(55 \AA)$ thick, which alternate with $3 \mathrm{~nm}(30 \AA)$ thick protein layers. An entire myelin lamella therefore measures about $17 \mathrm{~nm}$ across $(170 \AA)$ depending hydration. The lamellar structure of myelin was finally visualized by the advent of electron microscope by Fernández-Morán (1950), then Sjöstrand (1953) at the Stockholm Karolinska Institute, who provided a typical image of stacked lamellae. The spacing by electron microscopy showed an expected 30\% shrinking 
from fixation and dehydration, but maintained the difference between peripheral $(119 \AA)$ and central myelin $(107 \AA)$.

\subsection{Donaldson and Schmitt g ratio}

Around the turn of the 20th century, Henry Donaldson at the University of Chicago took a mathematical approach on myelin, calculating the surface areas of cross-sectioned axon and sheath. The invariability of their ratio prompted Donaldson and his student Hoke to systematically measure thousands of peripheral nerve fibers from 27 vertebrates representing the five main classes (fish, amphibians, reptiles, birds, and mammals including human).

Their tedious observation showed that despite a large variation in axon size, from minute rat axons to the largest skate axons, the myelin sheath remained strikingly proportional (Donaldson and Hoke, 1905). They inferred that the axon volume equaled that of the sheath, which was a point of remarkable similarity in vertebrates. Schmitt in 1937 also took a quantitative approach but on myelin birefringence, formerly essentially qualitative. Schmitt explained that polarized light entering anisotropic myelin splits the initial beam into two perpendicular refractive indices, $n_{1}$ and $n_{2}$, with one retarded with respect to the other by a distance $\Gamma$ (Greek gamma letter $\mathrm{g}$ ). This relative delay obviously depends on myelin thickness. The chief difficulty of quantifying birefringence resulted from the radial orientation of myelin lipids (Schmitt and Bear, 1937). Schmitt solved the problem by developing a mathematical equation including $\Gamma$, the fiber diameter $\mathrm{d}_{1}$ and the axon diameter $\mathrm{d}_{2}$ (Fig. 3). Schmitt was then struck by the continuity of the sheath birefringence curve plotted against the fiber diameter. In other words, the $g$ ratio (axon diameter/fiber diameter) variation had great continuity and a tendency to decrease with axon diameter. Schmitt also noted the sheath disappeared altogether for axons under $2 \mu \mathrm{m}$ diameter. Because Donaldson and Hoke (1905) studies were designed primarily to test constancy across species, but not across fiber range, Schmitt rightfully did not find his findings in conflict with Donaldson's. Further studies by Claes Hildebrand at the Karolinska Institute in Sweden would show that the $\mathrm{g}$ ratio in CNS, similarly as in PNS, increases with axon diameter then reaches a plateau (Hildebrand and Hahn, 1978). Hildebrand noted further species differences of a linear increase with axon diameter in mouse, while in frog the number of lamellae increased very slowly and was markedly curvilinear. These observations launched the complex biology of myelin thickness regulation still being deciphered.

\section{Mystery solved}

\subsection{Geren myelin spirals from Schwann cell}

The origin of such an exceptionally organized structure remained a mystery. The key person who solved it was Betty Ben Geren (1922- $\uparrow$ ), neuropathologist who graduated MD in 1945 at St. Louis Washington University followed by a pathology internship at Boston's Children's Hospital (Fig. 4). Geren received an American Cancer Society Research postdoctoral Fellowship to study with renowned F.O. Schmitt, and first addressed the question of whether myelin built by 'crystallizing out' droplets of lipid-protein, or started out as oriented layers. Geren observed by electron microscope a daily addition of layers inside the Schwann cell cytoplasm of chick embryo nerves (Geren and Raskind, 1953), but she was still reasoning with the prevailing concept of concentric layers. During frequent 
visits to MIT, Herbert Gasser, Nobel Prize winner in 1944 with Joseph Erlanger for physiological functions in single nerve fiber, made Geren familiar with the Schwann cell mesaxon surrounding unmyelinated fibers (Gasser, 1952). A year later, while waiting for the microscope to cool off at 2 a.m., Geren had a luminous insight: "I picked up the chicken sciatic prints for just another look when all of a sudden I saw Gasser's mesaxon, and then it was longer and then another picture it was spiraled- no wonder that this couldn't be appreciated by light microscopy. And then I knew that this was myelin beginning to form." (Geren personal communication). It explained why the myelin unit was composed of two membranes instead of one, which Schmitt could not fathom, and specified the layers were not concentric but spiraling (Fig. 4). This paper is arguably the most important ever published on myelin (Geren, 1954). The discussion speculated on possible compaction mechanisms, and Geren correctly suggested the drive of the inner mesaxon to extrude cytoplasm from myelin. Geren hypothesis initiated one of the most challenging 3-D problem to solve in biology, followed by decades of speculation on how the Schwann cell can spiral such a high number of myelin layers. Unfortunately, Geren images were spotty in this early age of electron microscope, and her publication was taken as a bold hypothesis rather than solid proof. It did not trigger immediate acclaim, although Nobel Prize Gasser did send a congratulation letter for her breakthrough discovery. Fate had Geren cross the path of same age MD biophysicist James David Robertson (1922-1995†) while he graduated for $\mathrm{PhD}$ with Schmitt (Fig. 4). Robertson, then a faculty at Kansas University, set to test Geren hypothesis, and obtained an early academic success by proving that myelin is really a spiral around the axon inside the Schwann cell cytoplasm (Robertson, 1955). Robertson was absolutely elated when he examined the micrograph with a hand lens and realized it showed exactly what Betty theory had predicted (Fig. 4). Robertson would pursue understanding membrane architecture in a series of outstanding ultrastructural papers during the 1950s1960s. He eventually devised the universal theory of "unit membrane" that all cell membranes consist of a bimolecular lipid leaflet with protein adsorbed to the surface (Robertson, 1962).

\subsection{Bunge oligodendrocytes also spiral myelin}

The studies of Geren and Robertson in the PNS triggered a rush by several laboratories to find a myelin spiral in CNS, but some prominent investigators concluded it did not exist (Luse, 1956; De Robertis et al., 1958). Luse (1956) provided evidence that oligodendroglia participate in the production of CNS myelin, but she held open the possibility that myelin is the product of other glial cells, while at the same time doubting the very existence of nodes. The case of De Robertis et al. (1958) is interesting because he was the first to show by electron microscopy a physical link between myelin and oligodendrocyte. He hence rightly believed CNS myelin was produced by oligodendroglia, but unfortunately rejected the concept of spiral, and instead interpreted that myelin layers were formed concentrically within oligodendrocyte cytoplasm. Technical problems of electron microscopy were very difficult to overcome in CNS. Introduction of fixation by osmium tetroxide (Palay et al., 1962) launched routine electron microscopy that allowed the analysis of structural relations between cells to an extent not formerly possible in the CNS. As these techniques were mastered, the laboratory of Richard Paul Bunge (1932-1996†) and his wife Mary Bartlett Bunge (Fig. 4) in New York Columbia University finally identified a spiral of myelin in 
CNS. Interestingly, they published the classic sophisticated model of CNS myelination (Bunge et al., 1961) before they could actually produce convincing electron micrographs after years of hard labor (Bunge et al., 1962; Bunge, 1968). The Bunges determined CNS myelin is formed by oligodendrocyte processes extending as much as $12 \mu \mathrm{m}$, a long distance at the ultrastructure scale. Stunningly, the Bunge laboratory discovered that a single oligodendrocyte generates multiple myelin internodes wrapped around different axons (Fig. 4). The 3-D problem of myelin wrapping in CNS was simply daunting when compared to PNS. The Bunges eventually made seminal contributions in Schwann cell biology, teaming with Patrick Wood, through tissue culture and transplant models. This led to Richard scientific direction of the Miami Project to Cure Paralysis. Mary Bunge is presently pursuing active research to promote spine functional regeneration.

\section{3. $1960 \mathrm{~s}$ Invertebrate diversity of ensheathment}

Only a cursory survey of the literature is presented here. In 19th century, the compact sheaths of invertebrate axons were referred to as myelin based on osmium staining and birefringence (Friedländer, 1889). Invertebrates glia were largely ignored until the advent of electron microscopy in the 1950s. Bullock and Horridge (1965) compiled the knowledge on glia in all invertebrate phyla in a monumental book that revealed axons are always surrounded by glial cells. Betty Roots (1927- $\dagger$ ) based in Toronto, Canada, spent her career studying invertebrate sheaths. Often, this is only a single layer of cells as in squid giant axons, but in many cases there are several overlapping layers referred to as loose-myelin. In annelids, phoronids and arthropods, multiple highly compacted layers resembling vertebrate myelin are found. One of the striking findings in invertebrates is their diversity. Sheaths of annelids differ radically from crustacea, as they are spirally wrapped whereas those of crustacea consist of concentric lamellae, implying radically different mechanism and regulation of myelination (reviewed in Roots, 2008).

The sheaths around giant fibers in the earthworms (Annelida), and around fibers in the eye stalk of the crab (Arthropoda) are remarkably similar to vertebrate myelin, with closely compacted lamellae held together by desmosome-like structures (McAlear et al., 1958; Hama, 1959), although lacking the characteristic specialization of desmosomes holding two cell membranes together very strongly (Roots and Lane, 1983).

Structures resembling Nodes of Ranvier were described in crustacea in early light microscopical studies (Retzius, 1890; Nageotte, 1916) and later by electron microscopy (McAlear et al., 1958; Heuser and Doggenweiler, 1966). In the earth worm, circular pores which act as nodes are found in the sheath (Günther, 1973). A detailed comparison between invertebrate and vertebrate nodes was carried out by Roots (1984).

Strikingly, the conduction velocity is increased, similarly as in vertebrates, in annelid (earth worm) and crustacean (prawn and shrimp). Not only do the sheaths increase the conduction velocity in axons, but saltatory conduction of action potentials is allowed by Node of Ranvier-like structures in crustacea and circular pores in the sheath in annelids. In the earthworm the sheath is not as efficient as vertebrate myelin (Günther, 1976), however, in shrimps the conduction velocity is over twice as fast as the fastest known vertebrate axon 
(Kusano, 1966). After a burst of interest in the 1960s-1970s no further studies were carried out on axon conduction velocity modulation by invertebrate glial sheaths.

Regarding the composition of invertebrate sheath membranes, it markedly differs from vertebrate myelin based on the little we know. Proteins in the earthworm and the pink shrimp are very different both from each other, and from vertebrate myelin (Pereyra and Roots, 1988; Okamura et al., 1986). The lipid composition is also very different from that of vertebrates (Okamura et al., 1986). According to Roots (2008) these differences in composition are not a justification for dismissing invertebrate sheaths as myelin, based on the differences found in vertebrates between CNS and PNS myelin, and between mammals and fishes.

\title{
10. Conclusion
}

Myelin can be conceived as a gigantic 3-D puzzle in time and space. The best scientists across the world have studied this structure directly or incidentally since the 18th century. Each of them brought a piece to the puzzle. Myelin was first reported as white matter inside the brain during the Renaissance. At the dawn of neuroscience in early 19th century, myelin was considered the most important element of the nervous system. After the axon was discovered, myelin went overlooked for decades by sheer ignorance of its function, but is now coming back full circle. Myelin has been tantalizingly difficult to understand, no doubt because of its tremendous structural and chemical complexity. It took three centuries to decipher its genesis and function. Several structural elements were rediscovered, illustrating the timeless rule of who and how new findings are published. We are getting close to fully understand the molecular mechanisms of this amazing biological structure, which allows us (our brain) to exist. Shall we say that the story of myelin has not yet ended and the last episode -myelin repair- is yet to be completed?

\section{Acknowledgments}

\author{
Funding \\ This work was supported by NIH/NLM grant G13LM011465.
}

We thank Jeffrey Dupree (Virginia Commonwealth University) for stimulating discussions on the origin of g-ratio. We are grateful to Boris Zalc (Paris Pitié-Salpêtrière Institute) for interactions on history of myelin. We are indebted to the Classic papers Network Glia website for providing access to quality 19th century plates. We thank Douglas Fields (National Institutes of Health, Bethesda) for providing personal recollection of Dr. Tasaki. We are grateful to Betty Geren (Arkansas family farm) and Richard Wiggins (West Virginia University) for context on the spiral of myelin discovery.

\section{List of abbreviations}

$\begin{array}{ll}\text { CNS } & \text { central nervous system } \\ \text { MIT } & \text { Massachusetts Institute of Technology } \\ \text { PNS } & \text { peripheral nervous system }\end{array}$




\section{References}

Boullerne AI. Neurophysiology to neuroanatomy: The transition from Claude Bernard to LouisAntoine Ranvier. Arch Ital Biol. 2011; 149(Suppl 4):38-46.

Bourneville, DM.; Guérard, L. De la Sclérose en Plaques disséminées. Adrien Delahaye; Paris: 1869.

Breathnach CS. Johann Ludwig Wilhelm Thudichum 1829-1901, bane of the Protagonisers. Hist Psychiatry. 2001; 12:283-296. [PubMed: 11951914]

Bullock, TH.; Horridge, GA. Structure and Function in the Nervous Systems of Invertebrates. Vol. 2. Freeman; San Francisco: 1965.

Bunge RP. Glial cells and the central myelin sheath. Physiol Rev. 1968; 48:197-251. [PubMed: 4866614]

Bunge MB, Bunge RP, Pappas GD. Electron microscopic demonstration of connections between glia and myelin sheaths in the developing mammalian central nervous system. J Cell Biol. 1962; 12:448-453. [PubMed: 13874658]

Bunge MB, Bunge RP, Ris H. Ultrastructural study of remyelination in an experimental lesion in adult cat spinal cord. J Biophys Biochem Cytol (J Cell Biol). 1961; 10:67-94.

Butt, AM. Structure and function of oligodendrocytes. In: Kettenmann, H.; Ransom, B., editors. Neuroglia. 3. Oxford University Press; New York: 2013. p. 62-85.

Cajal, SRy. Histologie du Système Nerveux de l'Homme et des Vertébrés. Maloine; Paris: 1909-1911.

Cajal, SRy. El aparato endocelular de Golgi de la célula de Schwann y algunas observaciones sobre la estructura de los tubos nerviosos. Trabajos del Laboratorio de Investigaciones Biológicas de la Universidad de Madrid. 1912; 10:221-246.

Cajal, SRy. Contribución al conocimiento de la neuroglia del cerebro humano. Trabajos del Laboratorio de Investigaciones Biológicas de la Universidad de Madrid. 1913; 11:255-315.

Charcot JM. Histologie de la Sclérose en Plaques. Gazette des hopitaux civils et militaires. 1868; 41:554, 557-558, 566.

Chinn P, Schmitt FO. On the birefringence of nerve sheaths as studied in cross sections. J Cell Comp Physiol. 1937; 9:289-296.

Clarke, E.; O'Malley, CD. A historical study illustrated by writings from antiquity to the twentieth century. University of California Press; Berkeley: 1968. The human brain and spinal cord.

Czermak, JN. Müller's Archiv für Anatomie, Physiologie und wissenschaftliche Medicin. 1849. Ueber die Hautnerven des Frosches; p. 252-271.

De Robertis E, Gerschenfeld H, Wald F. Cellular mechanism of myelination in the central nervous system. J Biophys Biochem Cytol. 1958; 4:651-656. [PubMed: 13587562]

del Río-Hortega P. El “tercer elemento" de los centros nerviosos. I La microgliá en estado normal. Bol Soc Esp Biol. 1919; 9:68-82.

del Río-Hortega P. ¿Son homologables la glía de escasas radiaciones y la célula de Schwann?. Boletín de la Sociedad Española de Biología, 10, 25-28 Translated in English by J.R Iglesias-Rozas and M Garrosa, 2012. Clin Neuropathol. 1922; 31:460-462. [PubMed: 23083464]

del Río-Hortega $\mathrm{P}$. La glie à radiations peu nombreuses et la cellule de Schwann sontelles homologables? C R Soc Biol Esp. 1924; 91:818-820.

del Río-Hortega P. Tercera aportación al conocimiento morfológico e interpretación funcional de la oligodendroglía. Memorias de la Real Sociedad Española de Historia Natural. 1928; 14:5-122.

del Río-Hortega P. Estudios sobre la neurologia. La glía de escasas radiaciones (oligodendroglía) Boletín de la Real Sociedad Española de Historia Natural, 21, 63-92 Translated in English by J.R Iglesias-Rozas and M Garrosa, 2012 Glia with very few processes (oligodendroglia) by Pío del Río-Hortega. Clin Neuropathol. 1921; 31:440-459. [PubMed: 23083463]

del Río-Hortega, P. Río-Hortega's third contribution to the morphological knowledge and functional interpretation of the oligodendroglia. Elsevier; London: 2013. (English translation of 1928 by J.R. Iglesias-Rozas and M. Garrosa with a biographical note)

Donaldson HH, Hoke GW. On the areas of the axis cylinder and medullary sheath as seen in cross sections of the spinal nerves of vertebrates. J Comp Neurol Psychol. 1905; 15:1-16. 
Ehrenberg CG. Nothwendigkeit einer feineren mechanischen Zerlegung des Gehirns und der Nerven vor der chemischen, dargestellt aus Beobachtungen. Ann Phys (Berlin). 1833; 28:449-473.

Fernández-Morán H. Electron microscope observations on the structure of the myelinated nerve fiber sheath. Exp Cell Res. 1950; 1:143-149.

Fontana F. Observations sur la structure des nerfs faites à Londres en 1779. Traité sur le Vénin de la Vipere. 1781; 2:187-208. (Florence).

Frankenhaeuser B. Saltatory conduction in myelinated nerve fibers. J Physiol. 1952; 118:107-112. [PubMed: 13000694]

Friedländer B. Über die markhaltigen Nervenfasern und Neurochorde der Crustaceen und Anneliden. Mittheilungen aus der Zoologischen Station zu Neapel. 1889; 9:205-265.

Fünfschilling U, Supplie LM, Mahad D, Boretius S, Saab AS, Edgar J, Brinkmann BG, Kassmann CM, Tzvetanova ID, Möbius W, Diaz F, Meijer D, Suter U, Hamprecht B, Sereda MW, Moraes CT, Frahm J, Goebbels S, Nave KA. Glycolytic oligodendrocytes maintain myelin and long-term axonal integrity. Nature. 2012; 485:517-721. [PubMed: 22622581]

Gasser, HS. Discussion of a paper by B. Frankenhaeuser (the hypothesis of saltatory conduction). In: Warren, KB., editor. Cold Spring Harbor Symposia on Quantitative Biology, Volume XVII: The Neuron. The Biological Laboratory, Long Island Biological Association; New York: 1952. p. 32-36.

Geren BB. The formation from the Schwann cell surface of myelin in the peripheral nerves of chick embryos. Exp Cell Res. 1954; 7:558-562. [PubMed: 13220597]

Geren BB, Raskind J. Development of the fine structure of the myelin sheath in sciatic nerves of chick embryos. Proc Natl Acad Sci U S A. 1953; 39:880-884. [PubMed: 16589348]

Göthlin, GF. Die doppelbrechenden Eigenschaften des Nervengewebes, ihre Ursachen und ihre biologischen Konsequenzen. Almquist and Wiksell; Uppsala: 1913.

Guillain, G. J-M Charcot sa Vie - son Oeuvre. Masson; Paris: 1955.

Günther J. A new type of "node" in the myelin sheath of an invertebrate nerve fibre. Experientia. 1973; 29:1263-1265. [PubMed: 4758935]

Günther J. Impulse conduction in the myelinated giant fibres of the earthworm. Structure and function of the dorsal nodes in the median giant fibre. J Comp Neurol. 1976; 168:505-531. [PubMed: 939820]

Hama K. Some observations on the fine structure of the giant nerve fibres of the earth worm Eisenia foetida. J Biophys Biochem Cytol. 1959; 6:61-66. [PubMed: 13673048]

Hermann, L. Handbuch der Physiologie, Part 1. Vogel; Leibzig: 1879.

Heuser JE, Doggenweiler CF. The fine structural organization of nerve fibers, sheaths, and glial cells in the prawn, Palaemonetes vulgaris. J Cell Biol. 1966; 30:381-403. [PubMed: 5968976]

Hildebrand C, Hahn R. Relation between myelin sheath thickness and axon size in spinal cord white matter of some vertebrate species. J Neurol Sci. 1978; 38:421-434. [PubMed: 310448]

Hirano A. A confirmation of the oligodendroglial origin of myelin in the adult rat. J Cell Biol. 1968; 38:637-640. [PubMed: 5664230]

Hodgkin AL. Evidence for electrical transmission in nerve. J Physiol. 1937; 90:183-232. [PubMed: 16994885]

Huxley AF, Stämpfli R. Evidence for saltatory conduction in peripheral myelinated nerve fibers. J Physiol. 1949; 108:315-339.

Jacobson, M. Foundations of Neuroscience. Plenum Press; New York: 1993.

Kettenmann, H.; Ransom, B. The concept of neuroglia: a historical perspective. In: Kettenmann, H.; Ransom, B., editors. Neuroglia. 2. Oxford University Press; New York: 2005. p. 1-16.

Kirschner DA, Hollingshead CJ, Thaxton C, Caspar DLD, Goodenough DA. Structural states of myelin observed by X-ray diffraction and freeze-fracture electron microscopy. J Cell Biol. 1979; 82:140-149. [PubMed: 479295]

Klebs E. Die Nerven der organischen Muskelfasern. Virchows Arch Pathol Anat Physiol Klin Med (Eur J Pathol). 1865; 32:168-198.

Kusano K. Electrical activity and structural correlates of giant nerve fibers in Kuruma shrimp (Penaeus japonicus). J Cell Physiol. 1966; 68:301-383. 
Lanterman AJ. Uber den feineren Bau der markhaltingen Nervenfasern (Schultze). Arch Mikrosk Anat. $1877 ; 13: 1-8$.

Lee Y, Morrison BM, Li Y, Lengacher S, Farah MH, Hoffman PN, Liu Y, Tsingalia A, Jin L, Zhang PW, Pellerin L, Magistretti PJ, Rothstein JD. Oligodendroglia metabolically support axons and contribute to neurodegeneration. Nature. 2012; 487:443-448. [PubMed: 22801498]

Lillie RS. Factors affecting transmission and recovery in the passive iron nerve model. J Gen Physiol. 1925; 7:473-507. [PubMed: 19872151]

Luse SA. Formation of myelin in the Central Nervous System of mice and rats, as studied with the electron microscope. J Biophys Biochem Cytol. 1956; 2:777-798. [PubMed: 13398444]

Mauthner L. Beiträge zur näheren Kenntnis der morphologischen Elemente des Nervensystems. Akad Wiss (Wien). 1860; 39:583-589.

McAlear JH, Milburn NS, Chapman GB. The fine structure of Schwann cells, nodes of Ranvier and Schmidt-Lanterman incisures in the central nervous system of the crab Cancer irroratus. $\mathrm{J}$ Ultrastruct Res. 1958; 2:171-176. [PubMed: 13631745]

Nageotte J. Incisures de Schmidt-Lanterman et protoplasma des cellules de Schwann. C R Soc Biol. $1910 ; 68: 39-42$.

Nageotte J. Notes sur les fibres à myéline et sur les étranglements de Ranvier chez certains crustacés. C R Seances Soc Biol Fil. 1916; 79:259-263.

Nageotte, J. Sheaths of the peripheral nerves. Nerve degeneration and regeneration. In: Penfield, W., editor. Cytology \& Cellular Pathology of the Nervous System. Hoeber; New York: 1932. p. 191-239.

Nemiloff A. Ueber die Beziehung der sogenannte "Zellen der Schwannschen Scheide" zum Myelin in den Nervenfasern von Säugetieren (Schultze). Arch Mikrosk Anat. 1910; 76:329-348.

Norton, WT.; Cammer, W. Isolation and characterization of myelin. In: Morell, P., editor. Myelin. 2. Plenum Press; New York: 1984. p. 147-195.

Norton WT, Poduslo SE. Myelination in rat brain: method of myelin isolation. J Neurochem. 1973; 21:749-757. [PubMed: 4271082]

Okamura N, Yamaguchi H, Stoskopf M, Kishimoto Y, Saida T. Isolation and characterization of multilayered sheath membrane rich in glucocerebroside from shrimp ventral nerve. J Neurochem. 1986; 47:1111-1116. [PubMed: 3746297]

Palay SL, McGee-Russell SM, Gordon S, Grillo MA. Fixation of neural tissues for electron microscopy by perfusion with solutions of osmium tetroxide. J Cell Biol. 1962; 12:385-410. [PubMed: 14483299]

Penfield W. Oligodendroglia and its relation to classical neuroglia. Brain. 1924; 47:430-452.

Penfield W. A method of staining oligodendroglia and microglia (combined method). Am J Pathol. 1928; 4:153-157. [PubMed: 19969784]

Penfield, W. Neuroglia: Normal and pathological. In: Penfield, W., editor. Cytology \& Cellular Pathology of the Nervous System. Hoeber; New York: 1932. p. 421-479.

Pereyra PM, Roots BI. Isolation and initial characterization of myelin-like membrane fractions from the nerve cord of earthworms (Lumbricus terrestris L.). Neurochem Res. 1988; 13:893-901. [PubMed: 2465500]

Ranvier L. Contributions à l'histologie et à la physiologie des nerfs périphériques. C R Acad Sci. 1871; 73:1168-1171.

Ranvier L. Recherches sur l'histologie et la physiologie des nerfs. Arch Physiol Norm Pathol. 1872; 4:129-149.

Ranvier, L. Traité technique d'Histologie. Librairie Savy; Paris: 1875-1885.

Ranvier, L. Leçons sur l'Histologie du Système nerveux. Librairie Savy; Paris: 1878.

Remak R. Vorläufige Mittheilung microscopischer Beobachtungen über den innern Bau der Cerebrospinalnerven und über die Entwickelung ihrer Formelemente. Müller's Archiv für Anatomie, Physiologie und wissenschaftliche Medicin. 1836:145-161.

Remak R. Weitere mikroscopische Beobachtungen über die Primitivfasern des Nervensystems des Wirbelthiere. Froriep's Neue Notizen. 1837; 3:35-41. 
Remak, R. Dissertation. Berlin: 1838. Observationes Anatomicae et Microscopicae de Systematis Nervosi Structura.

Retzius G. Zur Kenntniss des Nervensystems der Crustaceen. Biologische Untersuchungen [Neue Folge]. 1890; 1:1-50.

Robertson WF. On a new method of obtaining a black reaction in certain tissue-elements of the central nervous system (platinum method). Scott Med Surg J. 1899; 4:23-30.

Robertson, WF. Morbid conditions of the neuroglia. In: Robertson, WF., editor. Pathology in Relation to Mental Diseases. Clay; Edinburgh: 1900. p. 164-193.

Robertson JD. The ultrastructure of adult vertebrate peripheral myelinated nerve fibers in relation to myelinogenesis. J Biophys Biochem Cytol. 1955; 1:271-278. [PubMed: 13242592]

Robertson JD. The membrane of the living cell. Sci Am. 1962; 206:65-72. [PubMed: 14492825]

Roots, BI. Evolutional aspects of the structure and function of the nodes of Ranvier. In: Zagoren, JC.; Fedoroff, S., editors. The Node of Ranvier. Academic Press; Orlando, Florida: 1984. p. 1-29.

Roots BI. The phylogeny of invertebrates and the evolution of myelin. Neuron Glia Biol. 2008; 4:101109. [PubMed: 19508741]

Roots BI, Lane NJ. Myelinating glia of earthworm giant axons: thermally-induced intramembranous changes. Tissue Cell. 1983; 15:695-709. [PubMed: 6648952]

Rosenbluth J. A brief history of myelinated nerve fibers: one hundred and fifty years of controversy. $\mathbf{J}$ Neurocytol. 1999; 28:251-262. [PubMed: 10739568]

Sajous, CEdM. The Internal Secretions and the Principles of Medicine. 6. Davis Company; Philadelphia: 1914.

Schmahmann JD, Pandya DN. Cerebral white matter - historical evolution of facts and notions concerning the organization of the fiber pathways of the brain. J Hist Neurosci. 2007; 16:237-267. [PubMed: 17620190]

Schmidt HD. On the construction of the dark or double-bordered nerve fiber. Mon Microsc J. 1874; 11:200-221.

Schmidt, WJ. Die Bausteine des Tierkörpers in polarisiertem Lichte. Friederich Cohen; Bonn: 1924.

Schmidt WJ. Doppelbrechung und Feinbau der Markscheide der Nervenfasern. Z Zellforsch Mikrosk Anat. 1936; 23:657-676.

Schmitt FO, Bear RS. The optical properties of vertebrate nerve axons as related to fiber size. J Cell Comp Physiol (J Cell Physiol). 1937; 9:261-273.

Schmitt FO, Bear RS, Clark GL. X-ray diffraction studies on nerve. Radiology. 1935; 25:131-151.

Schmitt FO, Bear RS, Palmer KJ. X-ray diffraction studies on the structure of the nerve myelin sheath. J Cell Comp Physiol. 1941; 18:31-42.

Schultze, M. Allgemeines über die Structurelemente des Nervensystems. In: Stricker, S., editor. Handbuch der Lehre von den Geweben des Menschen und der Thiere. Wilhelm Engelmann; Leipzig: 1871. p. 108-136.

Schultze M, Rudneff M. Weitere Mittheilungen über die Einwirkung der Ueberosmiumsäure auf thierische Gewebe (Schultze). Arch Mikrosk Anat. 1865; 1:299-304.

Schwann, T. Microscopical Researches into the Accordance in the Structure and Growth of Animals and Plants. Sydenham Society; London: 1839. Mikroskopische Untersuchungen über die Uebereinstimmung in der Struktur und dem Wachsthum der Thiere und Pflanzen, Reimer, Berlin. Translated in English by H. Smith, 1847

Sjöstrand FS. The lamellated structure of the nerve myelin sheath as revealed by high-resolution electron microscopy. Experientia. 1953; 9:68-69. [PubMed: 13060329]

Tasaki I. The electro-saltatory transmission of the nerve impulse and the effect of narcosis upon the nerve fiber. Am J Phys. 1939; 127:211-227.

Tasaki I, Takeuchi T. Der am Ranvierschen Knoten entstehende Aktionsstrom und seine Bedeutung für die Erregungsleitung. Pflügers Arch gesamte Physiol Menschen Tiere (Eur J Physiol). 1941; 244:696-711.

Tasaki I, Takeuchi T. Weitere Studien über den Aktionsstrom der markhaltigen Nervenfaser und über die elektrosaltatorische Uebertragung des Nervenimpulses. Pflügers Arch gesamte Physiol Menschen Tiere (Eur J Physiol). 1942; 245:764-782. 
Thudichum, JLW. A Treatise on the Chemical Constitution of the Brain. Baillière; London: 1884.

Tourneux F, Le Goff R. Les étranglements des tubes nerveux de la moelle épinière. J Anat Physiol Norm Pathol. 1875; 11:403-404.

Valentin, G. Die Untersuchung der Pflanzen- und Thiergewebe im polarisierten Licht. Leipzig: 1861. van Leeuwenhoek, A. Delft, Adrianum Beman. 1719. Epistola XXXII. Epistolae Physiologicae Super Compluribus Naturae Arcanis; p. 309-317.

Vesalius, A. De Humani Corporis Fabrica Libri Septem. 1543.

Vignal, W. Développement des éléments du Système Nerveux cérébro-Spinal. Masson; Paris: 1889. Virchow R. Ueber das ausgebreitete Vorkommen einer dem Nervenmark analogen Substanz in den thierischen Geweben. Virchows Arch (Eur J Pathol). 1854; 6:562-572.

Virchow, R. Cellular Pathology. August Hirschwald; Berlin: John Churchill; London: 1858. Die Cellularpathologie in ihrer Begründung auf physiologische und pathologische Gewebelehre. Translated in English by F. Chance, 1860

von Kölliker, A. Handbuch der Gewebelehre des Menschen. 2. Wilhelm Engelmann; Leipzig: 1855. von Kölliker, A. Handbuch der Gewebelehre des Menschen. 4. Wilhelm Engelmann; Leipzig: 1863. von Lenhossék, M. Der feinere Bau des Nervensystems im Lichte neuester Forschungen. 2. Fischer's Medicinische Buchhandlung Kornfield; Berlin: 1895.

Zalc, B.; Rosier, F. La myéline: le Turbo du Cerveau. Odile Jacob; Paris: 2016. 

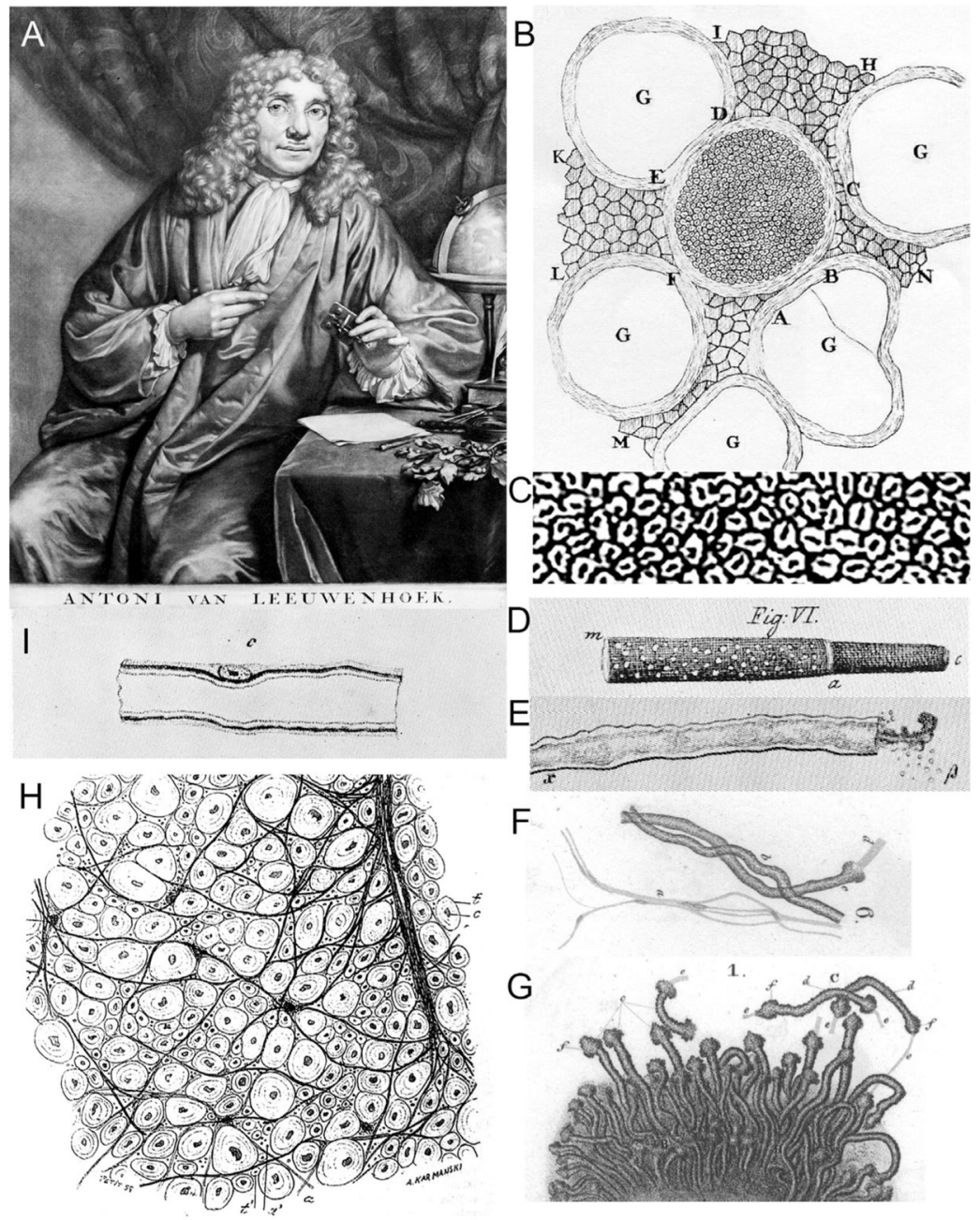

Fig. 1.

Early descriptions of myelin. A: Antoni van Leeuwenhoek by Verkolje painter in 1686 (courtesy London Wellcome Library). B: drawing of fresh spinal nerve section from cow or sheep (Fig. 2, van Leeuwenhoek, 1719) with detail in C showing the regular pattern of myelinated fibers. D: fresh primitive nervous cylinder partly stripped of its rough sheath on the right (Fig. 6 plate 4, Fontana, 1781). E: fresh frog spinal myelinated fiber: "a nerve tube with double wall containing the actual nerve marrow and the transparent structured brain tube which is quite transparent, emerging in $\beta$ " (Fig. 11, Ehrenberg, 1833). F: two fresh myelinated fibers (tubuli primitivi) with axon emerging in right and slender organic fibers (fibrae organicae) with nuclei (Fig. 6 plate 1, Remak, 1838). G: bovine myelinated fibers freed by pressure from its nerve showing primitive bands with rough sheath (axon with myelin) and pellucid primitive bands denuded of sheath (axon, gray threads); note the mushrooms of myelin at sections (Fig. 1 plate 1, Remak, 1838). H: bovine spinal cord section stained by carmine showing concentric myelin; $t$ is nervous tube; $c$ is axis-cylinder (Fig. 364, Ranvier, 1875-1885). I: Calf nerve fiber showing a nucleus in the Schwann sheath (Fig. 9 plate 4, Schwann, 1839). 

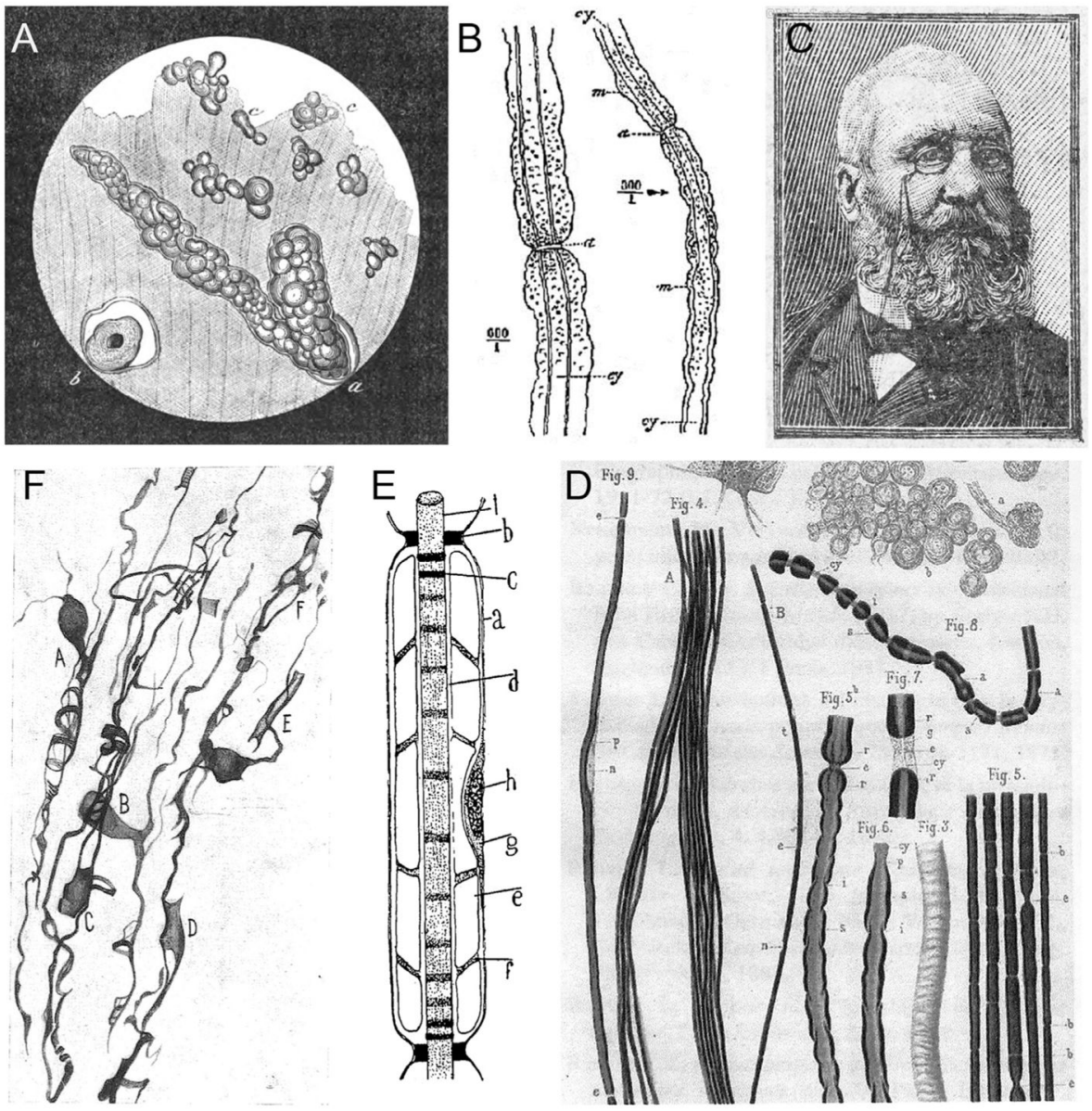

Fig. 2.

From chaos to order. A: drawing by Charcot (Fig. 1, 1868) of a fresh multiple sclerosis lesion showing disseminated myelin and fatty droplets. B: first representation of nodes at $300 \times$ and $600 \times$ from rabbit sciatic nerve stained by carmine; $a$ is node; $c y$ is axis-cylinder (axon); $m$ is myelin (Fig. 1 Ranvier, 1872). C: wood etching of Louis-Antoine Ranvier (courtesy Paris Descartes University Library). D: osmium blackening of myelin revealed the periodic segmentation of nodes across species from frog to rabbit; left Fig. 9 shows a complete internode with $e$ for étranglement (node), $n$ for nucleus and $p$ for protoplasm; Schmidt-Lanterman incisures are visible Figs. 5-6; top right corner are myelin balls from a fresh sciatic nerve dissociated in water, reminiscent of Charcot myelin globules; Fig. 3 shows a fresh nerve with white wrinkled myelin sheath (plate 1, Ranvier, 1878). E: complete schematic of a peripheral internode (Fig. 88, Cajal, 1909-1911). F: third type oligodendrocytes stained by silver carbonate whose processes spiraled around invisible myelin (Fig. 58, del Río-Hortega, 1928). 


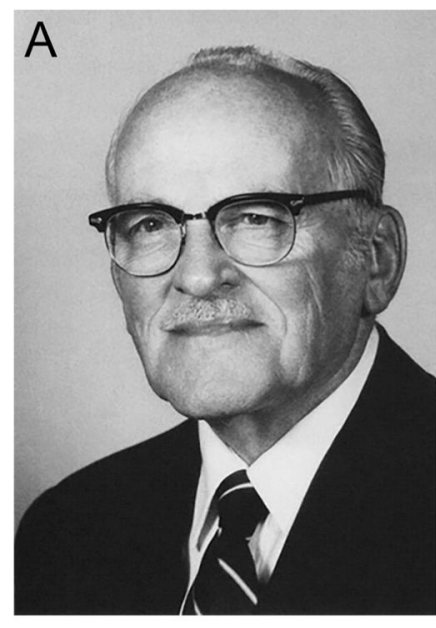

B
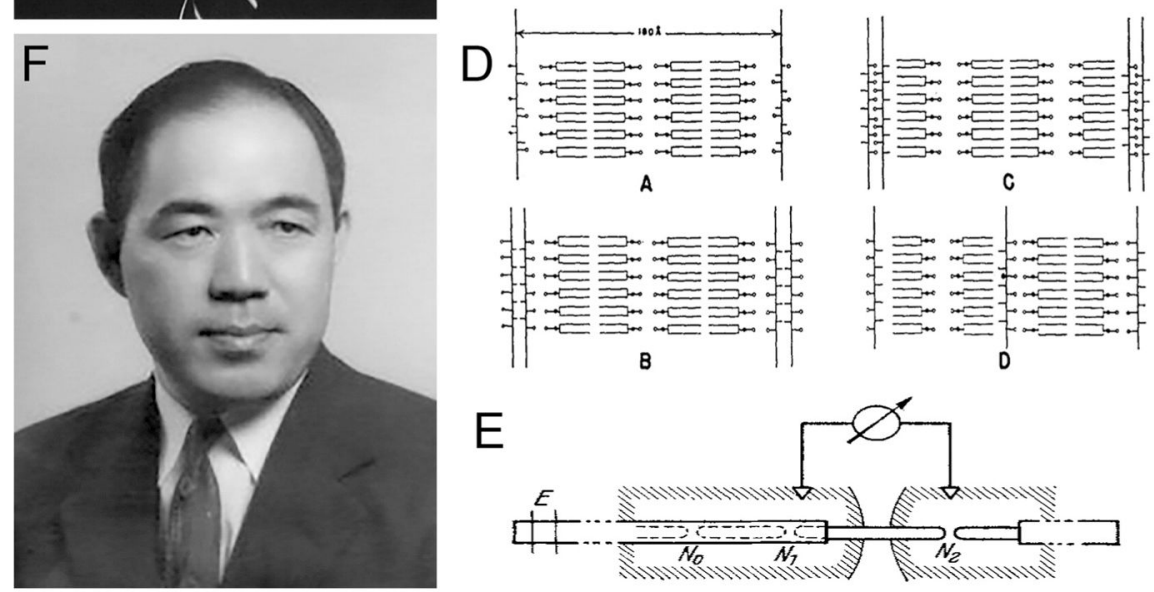

Fig. 3.

Crystalline organization and saltatory conduction. A: Francis Schmitt (courtesy American Philosophical Society), founding father of neuroscience, pioneer of X-ray diffraction and creator of $\mathrm{g}$ ratio. B: mathematical equation using the Greek capital letter $\mathrm{g}(\Gamma)$ and schematic of g-ratio (Fig. 1, Schmitt and Bear, 1937, reproduced from Wiley). C: X-ray diffraction of mouse nerve myelin showing concentric diffraction pattern (Fig. 1, Kirschner et al., 1979, reproduced from Rockefeller University Press). D: 4 models of myelin unit structure (Fig. 1, Schmitt et al., 1941, reproduced from Wiley). E: schematic of saltatory conduction from anesthetized nodes $N_{0}$ and $N_{1}$ to normal node $N_{2}$ after repeated stimulation of the axon in $E$ (Fig. 9, Tasaki and Takeuchi, 1942, reproduced from Springer). F: Ichiji Tasaki circa 1984 (courtesy Scholarpedia). 

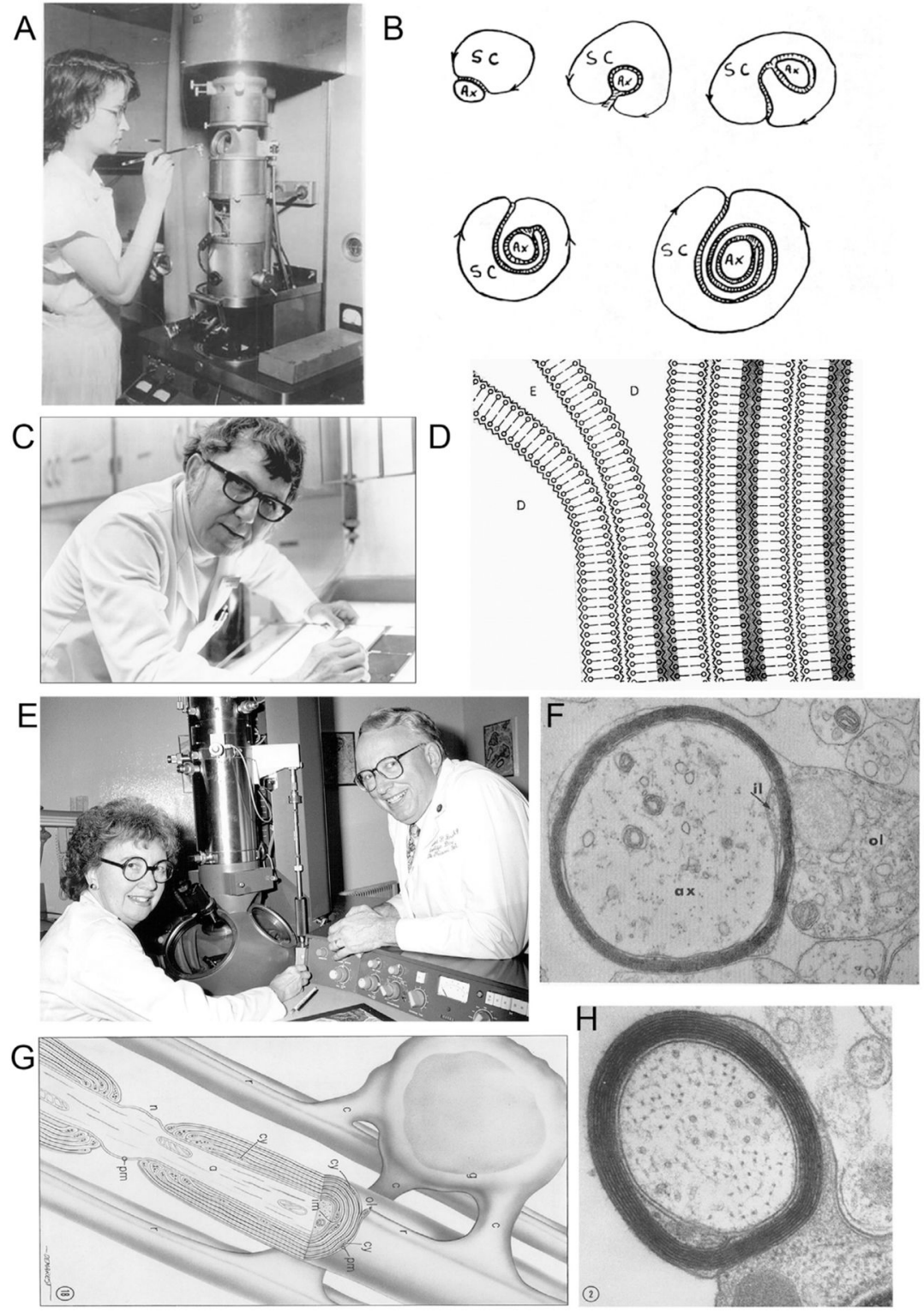

Fig. 4.

The origin of myelin: spiral from glia. A: Betty Geren at her electron microscope in the MIT basement circa 1950 (Geren courtesy) conceptualized the spiral of myelin. B: schematic of Schwann cell (SC) mesaxon spiraling myelin around the axon $(A X)$ (Fig. 5, Geren, 1954, reproduced from Elsevier). C: James Robertson at his light box (courtesy of American Society for Cell Biology), creator of the unifying membrane theory. D: schematic of myelin condensation (shaded) by extrusion of cytoplasm in $D$ and collapse of extracellular space in $E$ (Robertson, 1962, reproduced from Scientific American). E: Mary and Richard Bunge in their laboratory circa 1975 (courtesy Miami Project to Cure Paralysis) were the first to show oligodendrocytes spiral myelin in F (Fig. 7, Bunge, 1968, reproduced from the American Physiological Society). G: Bunges' hypothetical accurate schematic (Fig. 18, Bunge et al., 1961, reproduced from Rockefeller University Press). H: iconic electron microscopy image 
of oligodendrocyte making myelin (Fig. 2, Hirano, 1968, reproduced from Rockefeller University Press). 